\title{
Reflection of Indian Culture in Shashi Deshpande's A Matter of Time
}

\author{
Prajesh Jena
}

Research Scholar

Maharaja Sriram Chandra Bhanja Deo University

Baripada, Odisha, India

prajesh17jena@gmail.com

\begin{abstract}
Shashi Deshpande is a well-known name in the field of Indian literature and is a contemporary writer from Karnataka. She portrays in her novel "A Matter of Time" the truth of Indian society in Indian families. The importance of culture for Indian women is also discussed. Her novels are distinguished for their genuine depictions of the Indians and their history. She used Indian names and the role of Indian Middle Class Women in her novel A Matter of Time through the character Sumi. She talks about Indian Women, Indian Culture, Indian Religion, Indian Family, Religions and Beliefs, Family Traditions, and Emotions, among other topics. A Matter of Time is a multigenerational novel that moves around the plight and predicament of Indian women whose lives are deeply rooted in Indian beliefs, superstitions, conventions and traditions.

Women have been living and breathing silently for thousands of years under the umbrella of patriarchy and with their "gazing." With the foundation of patriarchy, the disparity between man and woman, in its unwritten form, has developed through language, customs, rituals, myths and practises. Myths, rituals, and customs contribute to the evolution and establishment of human society. They are naturally developed, but are indeed societal buildings and help in
\end{abstract}


developing patriarchal ideologies. They are believed to be natural. They are, therefore, essential to women's subjugation in our society.

Keywords: Patriarchy, Myth, Culture, Indian Family, Human Relationship

Shashi Deshpande's works have a strong Indian flavour and are classified as Indian English literature. Indian literature refers to work written in any Indian language in English. The word "Indian English Literature" underlines two main concepts. One, as its medium, is English, and the other, one of the many streams which enter the great oceans and is called Indian literature, even though it is written in a variety of languages. It is an English-language product. It is a product of Indian English that translates the sensitivity of the Indian language into English and the Indian culture into English. Indian English writing is a work that has established itself on the global market as a separate brand. Notably, its significance and formulation are inextricably linked to Indianness, a concept that is rich and complex, and includes various other concepts such as history, society, morals and religion. Despite its global reach, it is a concept of a rich and complex nature in many ways. Indian English authors have pushed the boundaries of language and literary techniques. Indian English literature is distinguished by the fact that it contains both authors who write about India from India and those who write about India from abroad. It also contains works by Indian Diaspora authors.

Indian Diaspora novelists dominate the contemporary Indian situation in English. Indian literature in English has only recently gained popularity thanks to the contributions of Indian Diaspora authors. There are a few obvious explanations for this. One of the reasons is that Diaspora authors use their talent, imagination, and learning to draw characters and themes from their native culture's greatest resources. The Diaspora is a global audience with increased access 
to readers worldwide. The writer from the Diaspora constructs and writes by trading tradition for tradition, culture and home for another.

The influence of colonialism on Indian culture and communities is shown in Indian English literature, which reflects cultural, political, educational, linguistic and cultural interactions and shifts in colonies. For decolonisation, the presentation of Indianness is used. There are elements of Indianness which represent diversity of life, unity in diversity and a rich culture. Many cultures have enriched Indian society, mingling spiritual and material aspects of life. It has the potential to be a source of inspiration for others, as well as having the unique ability to make its people proud of their heritage, as well as its role and significance in the modern era.

The term "Indianness" has sparked debate among critics, and many have attempted to define and explain it. The definition of Indianness in Indian English literature has a long and contentious history. They have been arguing over how to define Indianness for a long time. Many commentators have attempted to address the problem. In other words, Indianness is the product of an imaginative crossbreeding of Indian ideas and the English language. The style and diction as well as the atmosphere or background colour, imagery and literary styles will show indifference. An Indian writer is one who takes along not only a part of his entire Indian heritage but also knows about culture. Cultural consciousness is a major characteristic of Indianness. The sense of indignity imparts fusion to one another with the approval of such goodness without compromising the intrinsic goodness. The history of India shows that a lot of ruling Indians invaded India, but Indians maintained their own identity and took on other major characteristics of religion, society and culture. Indians are always conscious of being Indians. 
The stories of Shashi Deshpande deal with a woman: her sufferings and hardships, tensions and anguishes, pains and distresses. Deshpande primarily writes about India, the society of Indians and the indigenous culture. Her main concerns arise in her own environment and in the immediate world and hold mirrors in her own life. Her works, in particular novels, require the readers to pay unequalled attention to understanding the world without decoration.

Deshpande concentrates in her novels on Indian marital relations. In novels which adopt an open or understood feminist attitude, there is, however, a quantitative difference in tone and perception. The focus is not on the development or mechanics of the relationship, but on the forces that collaborate to make the relationship an absurd display of unity. According to the comments of Usha Bande, "Shashi Deshpande evolves a balance between traditional demands and modern compulsions and renegotiates power relations in an attempt to resolve the crisis" (191). She used the historical past here and there in this work, A Matter of Time. In this novel she uses the 'big house' of the name 'Vishwas.'

Indians, generally, are people who believe in idols of Gods, pujas, facts, rites and rituals. Though Kalyani's father Vithalrao was neither a religious man nor a believer in idols and rituals, he brought and installed a Ganapati idol in the niche above the front door of the house he was building. Kalyani's mother was not happy with this installation because it was too high to perform its puja. However, she performed her puja twice a month with the help of her servant who used to climb a ladder to clean it and offer some flowers to the idol. The tradition of performing puja is continued by Bora. Sumi knows:

... She cleans the idol with Nagi assisting and Kalyani watching. He wipes it with a wet cloth until the God emerges glossy and shining, clear of his filmy veil of dust and cobwebs, his pot belly gleaming, one leg daintly 
crossed over the other. Finally, putting a dot of kumkum on the forehead, Bora tucks a hibiscus behind one car and another in the loop of the trunk. Then climbing down the ladder, he looks with satisfaction at his work before folding his hands reverently. (Despande 115)

Kalyani too, imitating her mother, whom she must have seen performing such kind of puja as a child, continues her tradition, folds her hands and mutters: "Look after us, Ganapati, protects us". (Deshpande 115). It has been a common belief of Indians who believe in God that He looks after and protects us. However, Sumi, to her own surprise, responds by saying that God does not do such a good job of looking after women who suffer. She feels that the idol is only a piece of stone after all.

Indians believe that life and death are in the hands of god. They believe in the certainty of death and the immortality of the human soul. After Sumi and Shripati's accidental death, hundreds of people gather to attend their funeral ceremony. It is a strangely silent gathering of people. There is no loud display of sorrow, even from the family, either, with the exception of Charu. Aru and Charu watch their mother and grandfather leave the house never to return. They stand in an utter silence as their bodies are taken away. Gopal is staring at the river in which the ashes of the dead are mingled. He remembers and thinks over the word Runmukta uttered by the priest at the end of a small ceremony. He knows that the dead are free now, free of all human debts, human duties and responsibilities, free of everything. Human lives, the grief and mourning of the living for the dead, everything is ephemeral, everything passes, nothing remains. He believes:

Yes, Sumi is free, but at the cost of her body, of life itself. Is this freedom?

You must not grieve for the dead. Yes, don't grieve, because they have not 
gone, they are still with us, they will always be with us... But Sumi's body has gone, there is nothing left of it... We live through our bodies, we relate to the world, to others, through our bodies... But there's P. K. 's theory that death only means that your role is over and you go backstage into the darkness while the play goes on... I want to believe in it... I will learn to live with the knowledge that Sumi is dead... And yet, if Sumi has truly gone... why do I, sitting by this river, see her clearly? I can see her floating in, her body weightless, her face serene, smiling at me. I see her sitting on the river bank, her child in her arms, her face gleaming and beautiful in the twilight. (Deshpande 237-238).

He is haunted by Sumi's memory. It is difficult for him to forget her. He realizes that nothing ends; the dead leave their mark on the world, the mark that allows the living to live their lives in this world. He thinks to himself:

If, in reality, our fate is tied and it makes no sense to fight against it, it will remain - that we yield, not passively or shamelessly, but with pride and courage. Throughout his life, he'll take this feeling with him.

After a person has been buried, one brings out the Indian tradition of ashes. His ashes will be plunged into the river by the conviction that his soul is restful. It is an Indian culture and tradition and has been practised for many years. However, he says that he takes some of Sumi's ashes for immersion in the Alaknanda, a river. Sumi and he met together many years ago. He can not tell them that, as Sumi herself seemed to be, in its unrefined purity, the river flowed down the hills with a youthful exuberance. 
Similarly, Kalyani was so depressed when her son-in-law Gopal left her daughter. Shashi brings the suffering parents out of their martial life when their daughters fail. Marriage is a great thing, according to India's tradition. The Indians are concerned and give greater weight to it.

Deshpande explains the Spirit and the inheritance of a traditional Indian family in this novel, A Matter of Time. Kalyani asks Gopal to come back and live with Sumi. Kalyani is demanding the return of Gopal to live life with Sumi. Shashi Deshpande describes the Indian tradition here that man and woman should not live separately in India after marriage. Similarly, Kalyani doesn't want Sumi's life to be like her, because for thirty years her husband hasn't spoken with her. Shashi Deshpande speaks mainly in her works about the lives and sufferings of Indian women in their family and society.

The theme "life and death" is a major part of A Matter of Time. The figurehead Sumi passed away in an accident when she was ready to face life and the world with a new hope, after floundering for a long period of time. Similarly, the former actress, Rani (Devayani), had a car accident and serious injuries and her hope for her comeback in a dream project was destroyed. When asked about such a premature death and an unexpected accident, Shashi Deshpande stated that "death" and "accident" occur in real life and reflect that aspect of the truth.

To be entirely independent, she searches for a permanent job, learns to ride a double wheel, decides to move out of the house of her parents and looks for a new home. It demonstrates her willingness and independence and her desire to move from desperation to hope. After the desertion of Gopal, Sumi restores her creativity. She writes for the school function, which turns out to be a successful play, and she rejuvenates. "It feels so good and now suddenly I want to do many things" (231). She musters the courage to address more daring subjects, such as 
women's sexuality, and decides to write a new perceptive story about Suparnakha, King Ravana's Demon Sister. She thinks:

Suparnakha, neither ugly nor hideous, but a woman charged with sexuality, not frightened of displaying it - it is this Suparnakha I'm going to write about.

The characters in the novel slip from Kannada or Marathi unconsciously to English. This shift in language is meant to signify an altered relationship and the influence of place. The action takes place in Bangalore, where Sumi's relatives in Bombay, their Marathi influence and also their ancestor, Vishwas Rao, belonged to the Peshwa Marathas. The language has grace and smooth flow. The novel maintains curiosity by frequent fairy tales and philosophical insights from the Mahabharata, The Bible, Buddha and The Ramayana.

Gopal knows that we have a very complex relationship with the past. It is the past, in one way or the other, knowingly or unknowingly, reshapes our present, our life, our dreams and desires. The truth is that, he believes, whatever we do at the moment in our life gives the past some place in it. It is true that human life can be lived forward, but it can only be understood backward, and the past modifies the present. It is their preoccupation with the past which has brought Gopal and Kalyani, Gopal and Sumi together. However, Kalyani and Gopal look at the past in different ways. For Kalyani, everything in the world is preordained; we are mere instruments in the hands of destiny.

To her, even Bhagiratha's bringing the river Ganges down to the earth is not, as it is to Gopal, a magnificent act of human act of human determination. Yamunabai, the daughter of a well-to-do landlord, has a strong desire to work for the realization of her vision, her vision of doing something constructive for girls and women who live with nothing more in their lives than the slavery of endless drudgery and childbearing by giving them education. She, too, like 
Kayani, believes: We must never forget that we are the only instruments. (Deshpande 188). She believes in her mantra: Nimittamatram bhava Savyasachi-be thou only the instrument, Arjuna. The end is not us, it is outside us, it is quite separate from us. (Deshpande 188). According to Gopal, the plot of humankind evolves through our lives; it is the human will that sets all things in motion, it is the human desire that plays a constructive role in the drama of human life, and human beings carry the places of exile within themselves. He believes that the past and present are inseparable. He strongly believes:

Yes, we need to know our beginnings. Without that, we are forever exiles, forever homeless. It was only after the Pandavas... met their real fathers that they were fully armed and ready for war, armed with knowledge. But we don't really have to go out in search of our beginnings; it lies in us... Karna didn't need the armour Kunti had put on him when she abandoned him as a baby; the knowledge of his Kshatriyahood was part of him. It was through this knowledge that he reached an idea of himself... It's a fool's game trying to escape. (Deshpande 217-218).

Braj B. Kachru's Indianization theory is based on Shashi Deshpande's language in her novels, which demonstrates the unavoidable reality that English is no longer a foreign language, but rather the language of Indians. Deshpande believes in the study that Indian phrases can be conveniently handled in English. Women authors, in particular, feel themselves in English more relaxed and they have no linguistic complexities with their first language. So Shashi Deshpande is able to reveal the inner sensations of an Indian male and female person in her novels.

In a familial structure, a woman loses her freedom when she is bound in the institution of marriage and is entrusted with the burden of begetting a male-heir. This is justified and proved in the case of Manorama, Kalyani, and Sumi. Thus, keeping this at the central core of the novel, 
Deshpande shows this social evil that has been followed from generation to generation. At one stage, Sumi comes out of her suffering to attain freedom with courage and strength. Though the women characters are silenced in familial setup, they use silence as a tool and come out of their anguish to seek freedom.

In her works, Shashi Deshpande used Indianness with regard to the exclusive things of India. In particular, Shashi Deshpande has shown the Indian tradition and culture and the marital life of Indian women to highlight their Indianness. She has also given more importance to Indian culture, tradition and food, places, names, styles etc. 


\section{Bibliography}

\section{Primary Source:}

Deshpande, Shashi. A Matter of Time. Haryana: Penguin, 1996. Print.

\section{Secondary Sources:}

Bite, Dr. Vishwanath. Shashi Deshpande's Fiction. Jaipur: Aavishkar Publishers, 2013.Print.

Ranjita, H. The Changing Image of Woman in the Novels of Shashi Deshpande. New Delhi: Prestige Books, 2011. Print.

Sawant, Tukaram S. The Female World in Shashi Deshpande's Novels. New Delhi: Atlantic, 2017. Print.

Sisodiya, Suraj Singh. The Novels of Shashi Deshpande: Woman and Society. New Delhi: Prestige Books, 2014. Print. 